ROGER H. GORDON

Bell Laboratories

\title{
Interest Rates, Inflation, and Corporate Financial Policy
}

RECENT high levels of interest rates have had many effects on the economy. One particularly dramatic phenomenon associated with these high interest rates is an extraordinarily high bankruptcy rate. A related observation is that during the 1970 s both corporate debt-value ratios and nominal interest rates were nearly double their previous postwar values. ${ }^{1}$

The purpose of this paper is to analyze the possible economic links between interest rates, inflation, corporate financial policy, and the corporate bankruptcy rate in order to explain the above associations. The primary focus is on the role of interest rates and inflation in theoretical models of corporate financial policy. The paper provides an analysis of how changes in interest rates or inflation can lead to both higher debtvalue ratios and a higher bankruptcy rate; it also gives empirical estimates of the relative importance of expected interest rates and inflation and unexpected changes in interest rates and inflation in explaining the level and composition of corporate debt.

I thank members of the Brookings Panel for comments. I also thank Nancy Ng for ably performing the computations and Susan Pope for assistance in the early stages of the project. The views expressed in this paper are those of the author, and do not necessarily represent those of Bell Laboratories or of the Bell System.

1. For example, according to the figures in Gordon and Malkiel, between 1965 and 1975 the ratio of the market value of debt to the market value of the firms grew from 0.159 to 0.316 for the nonfinancial corporations on the Compustat tape. During that same period, the average yearly new issue AA corporate utilities interest rate grew from 4.57 to 9.50 . See Roger H. Gordon and Burton G. Malkiel, "Corporation Finance," in Henry J. Aaron and Joseph A. Pechman, eds., How Taxes Affect Economic Behavior (Brookings Institution, 1981), table 1, p. 158. 


\section{Theoretical Models of Corporate Financial Policy}

In the past, theoretical models of corporate financial policy have not focused on the effects of interest rates on financial decisions. Yet nominal interest rates play an important role in these models because it is nominal interest payments that appear in the tax law. However, the commonly cited models differ in their forecasts regarding the direction of effect of interest rates on debt-value ratios. The examination below of the empirical relation between interest rates and corporate financial policy provides a simple test of the relative importance of the effects isolated in the various models.

The modern literature on corporate financial policy really begins with articles by Modigliani and Miller. ${ }^{2}$ In their latest article, they argue that the U.S. corporate tax structure should lead firms to use solely debt finance, regardless of interest rates. Since that time, several theories have been proposed to reconcile this forecast with the observed limited use of debt finance by U.S. corporations. The most commonly cited theory argues that the tax advantage to using debt is in equilibrium just offset at the margin by the additional agency costs and possible bankruptcy costs incurred as a result of the extra debt. ${ }^{3}$ Most of this section explores the role of interest rates in this model.

Two alternative theories argue that there really is no tax advantage to debt finance in equilibrium. The first argues that as extra debt is added, the corporate tax advantage to using debt finance decreases since the probability of being unable to make use of interest deductions increases. ${ }^{4}$

2. See Franco Modigliani and Merton H. Miller, "The Cost of Capital, Corporation Finance, and the Theory of Investment, ' American Economic Review, vol. 48 (June 1958), pp. 261-97; Merton H. Miller and Franco Modigliani, "Dividend Policy, Growth and the Valuation of Shares," Journal of Business, vol. 34 (October 1961), pp. 411-33; and Franco Modigliani and Merton H. Miller, "Corporate Income Taxes and the Cost of Capital: A Correction,"' American Economic Review, vol. 53 (June 1963), pp. 433-43.

3. For recent developments of this argument, see James H. Scott, Jr., "A Theory of Optimal Capital Structure," Bell Journal of Economics, vol. 7 (Spring 1976), pp. 33-54; Gordon and Malkiel, "Corporation Finance"; Amir Barnea, Robert A. Haugen, and Lemma W. Senbet, "An Equilibrium Analysis of Debt Financing under Costly Tax Arbitrage and Agency Problems," Journal of Finance, vol. 36 (June 1981), pp. 569-81; and Franco Modigliani, Presidential Address, "Debt, Dividend Policy, Taxes, Inflation and Market Valuation," Journal of Finance, vol. 37 (May 1982, Papers and Proceedings, 1981), pp. 255-73.

4. See, for example, Harry DeAngelo and Ronald W. Masulis, "Optimal Capital Structure under Corporate and Personal Taxation," Journal of Financial Economics, vol. 8 (March 1980), pp. 3-29. 
In equilibrium the tax advantage falls to the point at which it is just offset by the unchanging personal tax disadvantage to debt (arising from a higher personal tax rate on interest payments than on a combination of dividends and capital gains). The second theory argues that, as persons in higher personal tax brackets must be induced to buy debt, the personal tax disadvantage to using debt in equilibrium becomes great enough to offset the unchanging corporate tax advantage to debt. ${ }^{5}$ The role of interest rates in these two alternative models is discussed later in this section.

\section{CORPORATE TAX ADVANTAGE VERSUS BANKRUPTCY COSTS}

The basic intuition in this model is simple. As a firm makes use of the net tax advantage to debt by borrowing to replace equity, the risk of bankruptcy rises. This higher risk implies a higher probability of real losses occurring during bankruptcy, higher monitoring and negotiating costs with potential lenders now, and a variety of agency costs, as managers attempt to aid equity holders at the expense of debt holders. ${ }^{6}$ It is argued that in equilibrium these costs become important enough at the margin to offset the unchanging tax advantage to debt.

The weakness of this approach is that researchers, attempting to quantify costs of bankruptcy, have not found cost comparable in size to the presumed tax advantages of debt. Warner, for example, found that legal and administrative costs incurred in bankruptcy tend to be only about 5 percent of the outstanding liabilities of the bankrupt firm. ${ }^{7}$ While the various types of agency costs could in principle be as large as the tax advantage to debt, there are no empirical measures to confirm this. ${ }^{8}$ Acceptance of the model must ultimately rest then on the accuracy of its implications, one of the more interesting being the relation that is forecast between interest rates and corporate financial policy.

5. See Merton H. Miller, Presidential Address, "Debt and Taxes," Journal of Finance, vol. 32 (May 1977, Papers and Proceedings, 1976), pp. 261-75.

6. For further discussion see Stewart C. Myers, "Determinants of Corporate Borrowing," Journal of Financial Economics, vol. 5 (November 1977), pp. 147-75; and Michael C. Jensen and William H. Meckling, "Theory of the Firm: Managerial Behavior, Agency Costs and Ownership Structure,' Journal of Financial Economics, vol. 3 (October 1976), pp. 305-60.

7. See Jerold B. Warner, "Bankruptcy, Absolute Priority, and the Pricing of Risky Debt Claims," Journal of Financial Economics, vol. 4 (May 1977), pp. 239-76.

8. See Michelle J. White, "Bankruptcy Costs: Theory and Evidence,"'Working Paper 287 (New York University, Salomon Brothers Center, 1981). 
In developing this explicitly, I begin by making the following simplifying assumptions:

There is only one form of debt and one form of equity, each of which can be bought and sold freely in the market. New debt is issued at par.

Debt and equity holders, when pricing their securities, demand the same after-tax, risk-free return and the same risk premium per "unit" of risk.

Tax factors are exogenous.

In the absence of taxes and bankruptcy-related costs, the ModiglianiMiller theorem is satisfied, implying that the firm is indifferent between debt and equity finance.

The argument is developed as follows. First the coupon rate and the market price of equity are derived at which investors are willing to purchase any given amount of debt and equity issued by the firm. In equilibrium the expected after-tax return on a security must provide the required after-tax, risk-free return on the funds invested, plus a suitable risk premium. Given the market valuation of debt versus equity, the firm then chooses to issue the quantity of debt that maximizes the value of the outstanding equity per share.

If the firm borrows $D$ dollars, lenders by competition charge a nominal coupon rate, $r$, which gives them a pattern of returns as attractive as that they can obtain elsewhere. For any given $r$, the expected after-tax return to bondholders is composed of several components. First, bondholders receive $r D$ in coupon payments, on which they pay tax at rate $m .{ }^{9}$ If the term structure of interest rates is not flat, they also expect a capital gain or loss, $g D$, in the market value of their bonds. In addition, there is a further expected capital loss, $(b+c) D$, due to the chance that the firm goes bankrupt and does not fully repay the money owed to the bondholders. (The distinction between $b$ and $c$ is explained below.) If the effective capital gains tax rate is $t_{g}$, the expected after-tax income to bondholders is $\left[\left(1-t_{g}\right)(g-b-c)+(1-m) r\right] D$. For higher values of $D$, one would expect $b$ and $c$, as well as $r$, to be larger.

By competition, $r$ will be set so that this expected return equals the

9. In the context of Brennan and Gordon-Bradford, $m$ would represent a weighted average of investor tax rates on interest income, where the wealthier and less risk averse get more weight. See M. J. Brennan, "Taxes, Market Valuation and Corporate Financial Policy," National Tax Journal, vol. 23 (December 1970), pp. 417-27; and Roger H. Gordon and David F. Bradford, "Taxation and the Stock Market Valuation of Capital Gains and Dividends,"' Journal of Public Economics, vol. 14 (October 1980), pp. 109-36. 
after-tax, risk-free return, $(1-m) i D$, where $i$ is the coupon rate on a risk-free bond, plus an appropriate risk premium, $\delta_{D} D$. Therefore, in equilibrium $^{10}$

$$
\left[\left(1-t_{g}\right)(g-b-c)+(1-m) r\right] D=\left[(1-m) i+\delta_{D}\right] D .
$$

Expected income to equity holders from the firm equals expected profits, $X$, after corporate taxes at rate $\tau$, plus any expected nominal capital gains due to inflation or to the approach of future profits, $G_{x}$, less the expected payments to bondholders. The coupon payments, $r D$, reduce after corporate tax income by $(1-\tau) r D$. In addition, in general, capital gains to bondholders during the period generate equivalent capital losses to equity holders. However, to the extent that there are real costs incurred in bankruptcy or inefficient decisions made due to the risk of bankruptcy, there could be some capital losses to bondholders that do not result in capital gains to equity holders. These are denoted by $c .{ }^{11} \mathrm{In}$ contrast, $b$ represents the expected losses to bondholders in bankruptcy that are just transfers to equity holders. If the effective personal tax rate on equity income is denoted by $e,{ }^{12}$ the expected after-tax return to equity holders is

$$
(1-e)\left[G_{x}+(1-\tau) X-(1-\tau) r D-(g-b) D\right] .
$$

10. If the expected size of bankruptcy losses $(b+c)$ is sufficiently sensitive to the size of the coupon payments that the firm makes, $r D$, there may be no $r$ satisfying equation 1 for sufficiently high values of $D$. For further discussion see E. Han Kim, "A MeanVariance Theory of Optimal Capital Structure and Corporate Debt Capacity," Journal of Finance, vol. 33 (March 1978), pp. 45-64.

11. The $c$ includes a component reflecting the cost of bearing the extra risk from these uncertain costs. Also, by construction, $c$ rather than $X$ captures the losses from inefficient investment decisions.

12. There are many unresolved issues about the personal taxation of equity income that make the appropriate treatment unclear. Both dividends and capital gains are subject to personal income tax under the law, with dividends taxed at a much higher rate. If the firm were to use the funds paid out as dividends to repurchase shares on the market, however, shareholders would receive the same income taxed at the lower capital gains rate. The heavier tax on dividends appears to be a voluntary tax, and it is unclear why it is paid. The effective tax rate on capital gains is also unclear. The tax is paid only when the capital gains are realized. The shareholder chooses when to realize the gains and has the incentive to realize losses early (perhaps short term) and postpone realizing gains. (If realization is postponed until death, no tax is due.) Indeed, Stiglitz hypothesizes that, as a result of realizing losses short-term and gains long-term, expected capital gains tax payments may even be negative. See Joseph E. Stiglitz, "Some Aspects of the Taxation of Capital Gains," Journal of Public Economics, forthcoming. 
At the equilibrium market value of the outstanding equity $E$, this expected after-tax income will be just sufficient to provide equity holders with the after-tax, risk-free return, $(1-m) i E$, that they could have obtained elsewhere, plus a suitable risk premium, $\delta_{E} E$. Therefore $E$ must satisfy

$$
\begin{gathered}
(1-e)\left[G_{x}+(1-\tau) X-(1-\tau) r D-(g-b) D\right] \\
=\left[(1-m) i+\delta_{E}\right] E .
\end{gathered}
$$

Adding equations 1 and 2, one obtains

$$
\begin{aligned}
& (1-e)\left[G_{x}+(1-\tau) X\right]+[\tau+e(1-\tau)-m] r D-\left(1-t_{g}\right) c D \\
& \quad+\left(e-t_{g}\right)(g-b) D=(1-m) i(D+E)+\left(\delta_{D} D+\delta_{E} E\right) .
\end{aligned}
$$

The left-hand side of equation 3 measures the expected income for both bond and equity holders. The second term on the left captures the advantage to using debt due to the tax treatment of coupon paymentsthe combined corporate and personal tax savings of equity holders when interest payments $r D$ are made, $[\tau+e(1-\tau)] r D$, while the extra taxes paid by bondholders are only $m r D .{ }^{13}$

The third term represents the offsetting real bankruptcy-related costs associated with the use of debt, while the fourth captures any difference between debt and equity holders in the tax treatment of expected transfers from one group to the other. The right-hand side measures the expected return required by bond and equity holders together. Since, by assumption, debt and equity holders charge the same price per "unit" of risk that they bear, the total risk premium, $\left(\delta_{D} D+\delta_{E} E\right)$, will not depend on how much debt versus equity is used in financing the firm.

What will characterize the optimal debt-value decision of the firm? The cost of adjusting financial policy is considered in a later section.

13. The presumption that $[\tau+e(1-\tau)]>m$ refers to large corporations only. Implicit estimates of $m$, made by comparing tax exempt with taxable interest rates as in Gordon and Malkiel, "Corporation Finance," or by comparing yields on discount bonds and newer issue bonds as in McCulloch, range around 0.25 to 0.30 , compared with a value of $\tau$ of 0.48 ( 0.46 recently). For small firms, the marginal corporate rate could be much lower, however, in which case the theory would imply a tax disadvantage to debt. Since Shiller and Modigliani, using different techniques, estimate higher values of $m$, the presumption that $\tau>m$ is not beyond question. See J. Huston McCulloch, "The Tax-Adjusted Yield Curve," Journal of Finance, vol. 30 (June 1975), pp. 811-30; and Robert J. Shiller and Franco Modigliani, "Coupon and Tax Effects on New and Seasoned Bond Yields and the Measurement of the Cost of Debt Capital," Journal of Financial Economics, vol. 7 (September 1979), pp. 297-318. 
Ignoring such costs for now, if the firm increases $D$ by one dollar, it can use the dollar to repurchase a dollar's worth of equity. If the market value of the remaining equity declines by less than a dollar, equity holders will prefer the extra debt. At the optimal value for $D$, an increase in $D$ of a dollar will result in exactly a dollar reduction in $E$. Therefore, by differentiating equation 3 with respect to $D$ and setting $\partial E / \partial D=-1$, one can characterize the optimal use of debt: ${ }^{14}$

$$
\begin{gathered}
(\tau+e(1-\tau)-m)\left[r+\frac{\partial r}{\partial D} D\right] \\
+\left(e-t_{g}\right)\left(g-\frac{\partial(b D)}{\partial D}\right)=\left(1-t_{g}\right) \frac{\partial(c D)}{\partial D} .
\end{gathered}
$$

Therefore, when it is optimal for the firm to use any debt at all, the increase in tax savings from more debt is just offset by an increase in real bankruptcy-related costs.

As is clear from equation 4, nominal interest rates as well as relative tax rates play a key role in determining the optimal amount of debt finance. For example, assume that the interest rate a firm faces depends linearly on the firm's debt-value ratio, so that $r=i+a(D / V)$, where $V$ is the value of the firm. ${ }^{15}$ Also assume that total bankruptcy costs, $c D$, can be approximated by $c D \approx c_{0} V(D / V)^{2}$, so that, given $D / V$, bankruptcy costs are proportional to the scale of the firm. ${ }^{16}$ If, for simplicity, $e=t_{g}$ so that any difference in tax treatment of transfers can be ignored, equation 4 simplifies to

$$
i\left[\frac{\tau+e(1-\tau)-m}{2\left\{c_{0}^{*}-a[\tau+e(1-\tau)-m]\right\}}\right]=\frac{D}{V},
$$

where $c_{0}^{*} \equiv\left(1-t_{g}\right) c_{0}$.

14. I assume that all the firm's debt has equal priority, so that the interest rate on all of the firm's debt rises to reflect the extra risk of bankruptcy when more debt is issued. I ignore the fact that it may be too late for existing bondholders to raise the interest rate they charge when new debt is issued.

15. Although use of the market value of the firm as a scaling factor is customary here, other measures (for example, liquidating value) might be proposed.

16. Since $c$ is itself a function of $D$, the expression $c D$ can depend in an arbitrary way on $D$. Here I assume, as in Gordon and Malkiel, "Corporation Finance," that bankruptcy costs are zero when debt is zero and that marginal bankruptcy costs, $\partial(c D) / \partial D$, increase linearly with $D$. 
Assume further that $c_{0}-a[\tau+e(1-\tau)-m]>0$, which ensures that the firm is not all debt-financed. Then, given the tax rates, the debtvalue ratio is proportional to nominal interest rates and is an increasing function of the tax advantage term, $[\tau+e(1+\tau)-m]$.

The linearity assumptions are arbitrary. In general, though, the debtvalue ratio still depends positively, but not linearly, on nominal interest rates. Since tax rates have not varied much over time, this model implies that nominal interest rates ought to have been a prime determinant of the debt-value ratio.

While there are many ways in which this model can be made more complicated, relaxing the initial assumptions has little effect on the important role of nominal interest rates in determining the equilibrium debt-value ratio. For example, it is frequently assumed that debt and equity holders have different required after-tax, risk-free rates of return or different risk premiums per "unit" risk. ${ }^{17}$ To be concrete, assume that risk-free returns differ due to tax differences alone, with $m_{D}$ as the personal tax rate of debt holders and $m_{E}$ (with $m_{E}>m_{D}$ ) as the personal tax rate of equity holders, and that $\delta \equiv \delta_{D} D+\delta_{E} E$ is an increasing and convex function of $D$. With these two changes, the first-order condition for $D$ becomes

$$
\begin{gathered}
{\left[\tau+e(1-\tau)-m_{E}\right] i+\left[\tau+e(1-\tau)-m_{D}\right]\left(r+\frac{\partial r}{\partial D} D-i\right)} \\
+\left(e-t_{g}\right)\left(g-\frac{\partial(b D)}{\partial D}\right)=\left(1-t_{g}\right) \frac{\partial(c D)}{\partial D}+\frac{\partial \delta}{\partial D}
\end{gathered}
$$

Again, the debt-value ratio is positively related to nominal interest rates, but now the weight on the risk-free component is less than the weight on the marginal risk premium in interest rates. Also, the tax advantage to extra debt is now offset partly by extra bankruptcy costs and partly by increased risk-bearing costs.

Another frequently questioned assumption is that "me-first" rules are satisfied. ${ }^{18}$ If me-first rules do not hold, existing bondholders,

17. See, for examr $\rightarrow$ Joseph E. Stiglitz, "Some Aspects of the Pure Theory of Corporate Finance: Bankruptcies and Take-Overs," Bell Journal of Economics, vol. 3 (Autumn 1972), pp. 458-82.

18. For example, as discussed in White, new loans can be secured by physical assets, in which case they implicitly have priority over older unsecured loans. See Michelle J. White, "Economics of Bankruptcy," Working Paper 286 (New York University, Salomon Brothers Center, 1981). 
participants in pension plans, or some other third party may be made worse off when the firm issues extra debt. If equity holders and the new lender together can gain at the expense of third parties when new debt is issued, the incentive to add extra debt is increased. For example, assume arbitrarily that the new lender bears only the fraction, $\alpha$, of any extra bankruptcy-related losses, $\frac{\partial(b+c) D}{\partial D}$, incurred as a result of the extra debt. Then the first-order condition for the optimal debt-value ratio, assuming that assumption 2 again holds, is

$$
\begin{gathered}
{[\tau+e(1-\tau)-m]\left(r+\frac{\partial r}{\partial D}\right)+\left(e-t_{g}\right)\left(g-\alpha \frac{\partial(b D)}{\partial D}\right)} \\
+(1-e)(1-\alpha) \frac{\partial(b D)}{\partial D}=\alpha\left(1-t_{g}\right) \frac{\partial(c D)}{\partial D}
\end{gathered}
$$

Of course previous lenders, given rational expectations, should have foreseen the possibility of these future issues. To the extent that bond covenants would not be adequate to prevent the extra issues, these previous lenders would have charged a higher coupon rate, but this existing higher coupon does not change the current incentive to add extra debt.

In this setting nominal interest rates still matter as before. Other factors may become more important, however. Presumably, for example, the standard set of bond covenants has grown more sophisticated over time, increasing the degree to which me-first rules hold.

The above model assumes that debt and equity holders price their securities as economic theory suggests. This assumption also is increasingly being questioned. For example, Modigliani and Cohn suggest that equity holders do not recognize that inflation increases the nominal value of the firm's capital stock. ${ }^{19}$ Specifically, they argue that the market ought to price equity based on equation 2 , reexpressed with real returns on each side, whereby

$$
\begin{gathered}
(1-e)\left[G_{x}^{R}+(1-\tau) X-(1-\tau) r D+\pi D-(g-b) D\right] \\
=\left[(1-m) i-\pi+\delta_{E}\right] E .
\end{gathered}
$$

Here $\pi$ is the inflation rate and $G_{x}^{R}$ is the expected real capital gains.

19. See Franco Modigliani and Richard A. Cohn, "Inflation, Rational Valuation and the Market," Financial Analysts Journal, vol. 35 (March-April 1979), pp. 24-44. 
However, they assert instead that the market prices equity based on

$$
\begin{aligned}
(1-e)\left[G_{x}^{R}+\right. & (1-\tau) X-(1-\tau) r D-(g-b) D] \\
= & {\left[(1-m) i+\delta_{E}\right] E . }
\end{aligned}
$$

If debt is still priced according to equation 1, managers, to maximize the market value of equity, will act just as described by equation 4 . The previous results carry through without change. But the deviation between the true economic value and the observed market value of the firm may make it inappropriate to measure $V$ in equation 5 by the firm's market value. ${ }^{20}$

More generally, the previous results carry through for any arbitrary expectations by the market for $G_{x}$ and $X$, as long as managers continue to maximize equity value per share. However, if managers have different, and presumably better informed, expectations about $G_{x}$ or $X$ than the market, they may choose to aid future shareholders by trading in equity to take advantage of their superior information. In particular, if they believe that equity is underpriced, they will borrow to repurchase equity-the arbitrage profits add to the incentive to increase debt. However, the firm must publicly announce its trading, so that rational investors in principle ought to infer from the firm's trading practice the nature of the firm's information-the more optimistic the managers, the more heavily they shift toward debt. The price ought then to reflect the information that the market learns, weakening the importance of this arbitrage by managers. ${ }^{21}$

Generalizing the previous results to handle more than two types of securities is also straightforward. Assume, for example, that there are debt issues with many different maturity dates. Let $D_{j}$ be the amount of debt maturing in $j$ months that is issued by the firm, with $D$ now denoting the total amount of debt. Let $r_{j}$ equal the coupon rate paid on debt $D_{j}$.

20. For example, assume that 5 is valid using the correct valuation for equity implied by 2 , but that the observed valuation for equity implied by $2 \mathrm{~b}$ is used when calculating the debt-value ratio. Then simple algebra implies that the observed debt-value ratio, $D / V$, exceeds the true debt-value ratio by the amount $(D / V)(1-e) \pi /\left[(1-m) i+\delta_{E}\right]$. Therefore, if this error in valuation has occurred, the observed debt-value ratio ought to have a strong positive relation with the inflation rate, even controlling for nominal interest rates.

21. As in Grossman and Stiglitz, some noise in the manager's trading rule would be necessary to achieve equilibrium. See Sanford J. Grossman and Joseph E. Stiglitz, "On the Impossibility of Informationally Efficient Markets," American Economic Review, vol. 70 (June 1980), pp. 393-408. 
For simplification, let $e=t_{g}$. Then, by generalization of the argument in the previous section, equation 3 can be rewritten as

$$
\begin{gathered}
(1-e)\left[G_{x}+(1-\tau) X\right]+\sum_{j} r_{j} D_{j}[\tau+e(1-\tau)-m] \\
-\left(1-t_{g}\right) c D=(1-m) i(D+E)+\left(\delta_{D} D+\delta_{E} E\right),
\end{gathered}
$$

where $c D$, the size of the total bankruptcy-related costs, depends on the size of each $D_{j}$, and $\delta_{D} D$ is the total risk premium on all the debt.

Differentiating with respect to the amount of debt at a particular maturity, $D_{s}$, and setting $\partial E / \partial D_{s}=-1$, gives

$$
[\tau+e(1-\tau)-m]\left[r_{s}+\sum_{j} D_{j} \frac{\partial r_{j}}{\partial D_{s}}\right]=\left(1-t_{g}\right) \frac{\partial(c D)}{\partial D_{s}} .
$$

As before, the left-hand side measures the tax savings that arise from increasing $D_{s}$ by a dollar, and the right-hand side measures the resulting increase in bankruptcy-related costs.

Equation $4 \mathrm{c}$ shows that the optimal $D_{s}$ depends critically on the prevailing nominal interest rate, $r_{s}$, for that particular maturity. To illustrate, assume that $r_{s}=i_{s}+\sum_{j} a_{j}^{s}\left(\frac{D_{j}}{V}\right)$, where $i_{s}$ is the interest rate on default-free debt of that maturity. ${ }^{22}$ Also assume that $c D=c_{0} V\left(\frac{D}{V}\right)^{2}\left[1+\sum_{j} \frac{1}{d_{j}}\left(\frac{D_{j}}{D}\right)^{2}\right]$. Here the previous quadratic term is multiplied by an expression capturing the idea that concentrating a given amount of debt in a particular maturity may be increasingly risky because it all comes due at once. With these assumptions, $4 \mathrm{c}$ simplifies to

$$
\begin{aligned}
\frac{D_{s}}{V} & =\frac{d_{s}}{2 c_{0}^{*}}\left\{[\tau+e(1-\tau)-m]\left[i_{s}+\sum_{j} a_{j}^{s}\left(\frac{D_{j}}{V}\right)\right]\right. \\
& \left.-2 c_{0}^{*} \frac{D}{V}+[\tau+e(1-\tau)-m] \sum_{j} a_{j}^{s}\left(\frac{D_{j}}{V}\right)\right\} .
\end{aligned}
$$

22. In general, the risk-free coupon rate, $i_{s}$, can vary by maturity. However, when it does, expected capital gains, $g_{s}$, must vary in an offsetting way so that the total after-tax return, $g_{s}+(1-m) i_{s}$, is the same for all maturities. The $i$ on the right-hand side of $3 \mathrm{a}$ represents the equilibrium coupon rate when there is no expected change in capital value. 
The set of equations in 5a, one for each maturity length $s$, implies for example that the relative use of short-term versus long-term finance depends positively on the level of short-term versus long-term interest rates. This is true even though the expectations theory of the term structure makes the present discounted value of interest payments equal for all financing strategies. The reason is that there is an advantage to taking high interest deductions sooner rather than later. The relation between short-term interest rates and short-term financing is not simple, however.

Thus far I have avoided relaxing the assumption that tax rates are exogenous in order to sharply differentiate the model of tax advantage versus bankruptcy costs from the DeAngelo-Masulis model, in which $\tau$ is endogenous, and the Miller model, in which $m$ is endogenous. In both alternative models, bankruptcy costs are normally assumed not to exist.

\section{ENDOGENOUS CORPORATE TAX RATE}

The corporate tax rate may be endogenous because of the progressivity of the corporate tax law, and, in particular, because of the lack of refundability when the firm has tax losses. Carry-back and carry-forward provisions in the tax law, transfer of tax deductions through leasing (which was made much easier in the 1981 Economic Recovery Act), and mergers of firms to make use of tax losses serve to equalize marginal tax rates over time and among firms. ${ }^{23}$ To the extent that tax rates are not fully equalized, however, the firm's expected marginal corporate tax rate may change as its financial policy changes. That is, with extra interest deductions, the firm is more likely to be in a lower tax bracket.

If one allows $\tau$ to be endogenous in the above derivation, the firstorder condition for $D$ becomes ${ }^{24}$

23. As an indication of the limited importance of the lack of refundability in the corporate tax law, for the firms on the Compustat tape, aggregate tax loss carried forward averaged 5.6 percent of aggregate corporate tax payments. Of the aggregate tax losses carried forward into the next tax year, on average 26.2 percent were used up reducing tax payments in that year. For figures from a broader cross-section of firms suggesting greater importance of the lack of refundability, see Joseph J. Cordes and Steven M. Sheffrin, "Taxation and the Sectoral Allocation of Capital in the U.S.," National Tax Journal, vol. 34 (December 1981), pp. 419-32.

24. When the marginal corporate tax rate is endogenous and corporate taxable income is stochastic, expected corporate tax payments in 3 can be expressed as $\int_{r D}^{\infty}\left[\int_{0}^{X-r D} \tau(a) d a\right] f(X) d X$, where $\tau(a)$ is the marginal tax rate when taxable income is $a$ 


$$
\begin{gathered}
{[\bar{\tau}+e(1-\bar{\tau})-m]\left(r+\frac{\partial r}{\partial D} D\right)} \\
+\left(e-t_{g}\right)\left(g-\frac{\partial(b D)}{\partial D}\right)=\left(1-t_{g}\right) \frac{\partial(c D)}{\partial D} .
\end{gathered}
$$

The only change is that $\tau$ is replaced by the expected marginal tax rate, $\bar{\tau}$. Again, nominal interest rates play an important role.

If the movement in $\bar{\tau}$ is the primary process leading to equilibrium, however, the relation between nominal interest rates and the equilibrium amount of debt is more complicated. Assume for simplicity, as do DeAngelo and Masulis, that $c=0$ and that $e=t_{g}=0$. Then equation $4 \mathrm{~d}$ implies that in equilibrium $\bar{\tau}=m$, regardless of the level of nominal interest rates. However, $\bar{\tau}$ itself depends in part on the size of nominal rates. If nominal interest rates increase, interest deductions increase (immediately on short-term debt and gradually for long-term debt). Everything else being equal, the amount of debt would have to drop for interest deductions and $\bar{\tau}$ to remain unchanged.

If the rise in nominal rates were accompanied by a rise in the inflation rate, inflation would cause the real value of depreciation deductions and inventory deductions to fall (for firms using the FIFO, or first in, first out method). The drop in the value of these deductions would imply by itself an increase in the incentive to use debt. Viewed as a function of both $r$ and $\pi$, however, $D$ ought to increase as $\pi$ increases, given $r$, and fall as $r$ increases, given $\pi$. This conclusion contrasts sharply with that from the model of the tax advantage versus bankruptcy costs, in which $D$ increases as $r$ increases, and $\pi$ plays a small role. Of course, the two theories are not mutually exclusive.

\section{ENDOGENOUS PERSONAL TAX RATE}

Thus far it has been assumed that the individual tax rates, $e, m$, and $t_{g}$, are exogenous to changes in a firm's financial structure. The rationalization for this treatment can be found in Brennan and in Gordon and

and $f(X)$ is the density function of $X$. Differentiating with respect to $D$ gives $-\left[\int_{r D}^{\infty} \tau(X-\right.$ $r D) f(X) d X] \frac{\partial(r D)}{\partial D} \equiv-\bar{\tau} \frac{\partial(r D)}{\partial D}$, where $\bar{\tau}$ is the expected marginal tax rate. With this change, the derivation of $4 \mathrm{~d}$ proceeds as before. 
Bradford. ${ }^{25}$ These papers show that when tax rates vary among individuals and when those individuals can buy and sell all assets without constraints, the effective tax rates characterizing market equilibrium prices are simply weighted averages of the corresponding tax rates of each individual investor, where each weight depends on the investor's wealth and his degree of risk aversion. If each individual's tax rate is exogenous to a firm's behavior, the weighted average will effectively be exogenous also.

This conclusion is not robust, however. For example, when individuals face constraints in their portfolio behavior, such as borrowing constraints and short sales constraints, as discussed in Auerbach and King, the tax rates characterizing market equilibrium can well vary as firms change their financial policy. ${ }^{26}$ The implicit market tax rates now depend on the degree to which these various constraints are binding, as well as on the weighted average of individual tax rates.

If one allows personal tax rates to be endogenous in the above derivation for the optimal use of debt by a firm, the first-order condition for a firm shown in equation 4 would not change in form, assuming that each firm is small enough to act as a price taker with respect to the market-wide implicit prices, $m, e$, and $t_{g}$. Even if each firm treats these prices as given, however, they will gradually adjust as firms together change their policies. In particular, as more debt is issued, investors in higher tax brackets must be induced to buy some of it, raising the marketwide tax rate, $m$. In the simplified setting of Miller in which $c=e=t_{g}$ $=0$, equilibrium is reached when $m$ rises to the point that $m=\tau$. Since each firm takes $m$ and $\tau$ as given, however, each firm is indifferent to how much debt it issues. The aggregate amount of debt must be large enough, however, to drive $m$ to the value $\tau$.

If the endogeneity of $m$ is the sole process leading to an equilibrium, how should the aggregate amount of debt respond to a change in the level of market interest rates? Several types of indirect effects could occur. First, a rise in market interest rates raises the size of capital income, driving investors into higher tax brackets. The resulting rise in

25. See Brennan, "Taxes, Market Valuation and Corporate Financial Policy," and Gordon and Bradford, "Taxation and the Stock Market Valuation."

26. See Alan J. Auerbach and Mervyn A. King, "Taxation, Portfolio Choice and DebtEquity Ratios: A General Equilibrium Model,'’ Quarterly Journal of Economics, forthcoming. 
$m$, everything else being equal, causes the equilibrium amount of debt to fall. Similarly, a rise in interest rates that is accompanied by inflation drives investors into higher tax brackets, again lowering the equilibrium amount of debt. In addition, however, a rise in rates raises the importance to investors of differences in the tax treatment of debt versus equity relative to risk considerations. This causes further specialization in portfolios, everything else being equal, concentrating the existing debt in the hands of those with lower tax rates, and thereby lowering $m$. The equilibrium amount of debt increases as a result.

In general, the theoretical relation between interest rates and aggregate debt described above would be compounded by these additional factors.

\section{ENDOGENEITY OF THE FUNCTION $c(D / V)$}

The bankruptcy cost function has been assumed to be exogenous up to this point. In this section I briefly note a number of reasons why $c$ might vary among firms and over time.

Clearly when the future value of the firm is more uncertain the risk of default and the size of agency costs both grow more quickly as the amount of debt outstanding increases. One would therefore expect debtvalue ratios to be lower both for individual firms whose value is relatively more volatile and in aggregate at dates when the value of firms tends to be more volatile.

The function $c$ also shifts when the bankruptcy law (statutory or case law) changes, as it did, for example, in 1979. Similarly, increasing sophistication over time in designing the various covenants in bond contracts should lead to a gradual decline in agency costs, and an upward drift in debt levels.

Inflation may also have an effect on bankruptcy costs. For a firm to be forced into bankruptcy, not only must there be no source of new outside finance, but also the firm must default on its existing claims. It can continue as long as its current cash flow is sufficient to avoid defaulting on any required payments. Inflation, however, creates cashflow pressure on the firm, since current coupon payments must be larger to compensate for the depreciation in the real value of the outstanding principal. With a higher inflation rate, the firm is therefore less likely to survive without outside finance based on its cash flow alone. While the 
higher probability of bankruptcy by itself raises $c$, the faster speed with which bankruptcy occurs lessens the opportunity to invest in inefficiently risky projects in an attempt to save the firm (as described in Myers), thereby lessening agency costs. Thus it is unclear whether inflation raises or lowers $c$.

One final question that might be raised about the function $c$ is how different types of debt affect it. Debt instruments have different maturities, and market and book values differ. The size of $c$ depends primarily on the probability of going bankrupt at each given date in the futureagency costs as well as costs during bankruptcy are linked to these probabilities. What, then, determines the probability of bankruptcy in the coming period? Under what conditions would no one be willing to extend further credit at the end of the period? There does not seem to be a straightforward answer.

If all the firm's creditors expect it to survive, the firm could obtain ample credit and would in fact survive. The expectation is self-fulfilling. Similarly, if all creditors expect the firm to fail, it would seem that the firm could obtain no outside funds and would in fact fail (unless its cash flow could keep it going). If it did fail, however, a new creditor might still be fully compensated. If the firm liquidated, then full compensation would occur if the book value of the existing claims were less than the sale value of the assets. If the firm reorganized, then the outcome is less clear. In general, in reorganization the firm can continue a current debt contract or replace it with a new contract of equal book value, as it chooses, so that full payment to the new creditor can occur if the sum of the minimum of the book or the market value of each liability is less than the operating value of the assets. I assume here that no new credit will be available if a sudden shift in expectations could lead to an immediate loss to the new lender.

Even if the firm can obtain no new credit, it may be able to continue if its cash flow is sufficient. This is less likely when more of its debt is short term. In addition, to the degree that the market value of long-term debt exceeds the book value, the firm has an incentive to reorganize, so it may declare bankruptcy.

While the one-period probability of bankruptcy depends primarily on the book value of the outstanding debt, the longer-term probability depends primarily on the market value of the debt. Whether the firm can eventually repay its obligations depends on their present value relative to the value of the firm's assets. 
Finally, new long-term debt differs from shorter-term debt in the variability of its market value. This extra variability may increase or decrease the eventual probability of bankruptcy, depending on the correlation of movements in the market value of long-term debt with the market value of the firm. ${ }^{27}$

In conclusion, $c$ depends in a complicated way on many of the characteristics of the outstanding liabilities relative to the value of the firm's assets.

\section{Unexpected Changes in Interest Rates}

Because corporations cannot instantaneously readjust their financial policy in response to new developments, observed debt-value ratios will reflect in part the effects of unexpected changes. Unexpected changes can affect both the market value of the firm and the market value of the firm's liabilities. For example, any unexpected increase in interest rates lowers the market value of long-term debt, but should not affect the value of short-term debt, and does not affect the book value of long-term debt. ${ }^{28}$ Unexpected changes in the inflation rate, holding nominal rates constant, should not affect the value of debt, except perhaps through changes in bankruptcy risk.

Unexpected changes in interest rates and in inflation will affect the total value of the firm in a variety of ways. Increases in the real after-tax discount rate reduce the value of the firm, implying that a rise in the nominal rate, given inflation, raises debt-value ratios, and a rise in the inflation rate, given nominal interest rates, causes them to fall. ${ }^{29}$ If a rise in the discount rate creates fear of a recession, or raises the risk premium, then the drop in firm value is accentuated. Changes in inflation also affect

27. If movements in the nominal interest rate are primarily changes in the real discount rate as well, shocks to the market value of long-term debt will be positively correlated with shocks to the value of the firm, making long-term debt less risky than short-term debt. In contrast, if the discount rate does not move in parallel, long-term debt may be riskier than short-term debt.

28. The degree to which the market value of long-term debt responds to unexpected changes in nominal interest rates depends in part on the nature of any call provisions on the long-term debt and on how close the current price is to the call price.

29. If the hypothesis of Modigliani and Cohn is correct, changes in the discount rate arise solely from changes in nominal interest rates because investors are assumed to mistakenly use nominal rather than real discount rates. Unexpected changes in the inflation rate, given nominal interest rates, should then have little effect on debt-value ratios. 
expected tax payments, due to historical cost depreciation and FIFO inventory accounting, while changes in the interest rate affect the value of future nominal interest deductions. Each of these effects is in the opposite direction from the discount rate effect. In addition, unexpected changes in both interest rates and inflation may be correlated with unexpected changes in profitability.

\section{Costly Adjustment of Financial Policy}

Up to this point, it has been assumed that a firm can costlessly readjust its financial policy at any date even if, as in the previous section, in practice there are lags in such adjustments. This assumption can easily be questioned. In particular, there seem to be plausible reasons why the firm will find it costly to change the amount of its equity outstanding. Firms seem reluctant to change their dividend payment, making additions to retained earnings difficult. ${ }^{30} \mathrm{New}$ equity issues require approval by the Securities and Exchange Commission, creating expense and delays, and marketing costs for new issues are not insubstantial. Conversely, repurchase of equity is also viewed as being costly-some theorists even assume that it cannot be done at all. ${ }^{31}$

While the nature and magnitude of these costs are unclear, I explore here the implications of the assumption that changes in equity are increasingly costly to the extent that they involve changes in dividend payments or repurchases or new issues of equity. Because borrowing (or retiring debt) is an alternative to changes in equity, these costs of changing equity provide an incentive to smooth any desired changes in equity and to vary debt rather than equity in response to short-term changes in the firm's cash flow. Over time, the debt-value ratio will gradually be brought back into line.

To make the argument explicit, let $f_{t}$ denote the net cash flow in the firm in period $t$-after-tax profits net of interest payments and desired dividends plus capital consumption allowances. Funds available for new

30. A signaling role for dividends may explain this stability in the dividend payout rate. See Sudipto Bhattacharya, "Imperfect Information, Dividend Policy, and 'The Bird in the Hand' Fallacy," Bell Journal of Economics, vol. 10 (Spring 1979), pp. 259-70.

31. See, for example, Alan J. Auerbach, "Wealth Maximization and the Cost of Capital,"' Quarterly Journal of Economics, vol. 93 (August 1979), pp. 433-46. 
investment, $I_{t}$, then equal $f_{t}$ plus additions to debt, $D_{t}-D_{t-1}$, plus new equity, $\Delta E_{t}$, obtained either through cuts in the dividend or new issues. The gain in the value of the firm resulting from the new investment is denoted by $v\left(I_{t}\right)$. New equity issues generate costs, however, which are denoted by $n\left(\Delta E_{t}\right)$. The function $n\left(\Delta E_{t}\right)$ is assumed to be positive and convex, with a minimum at $\Delta E_{t}=0$.

Since $I_{t}$ depends on the size of additions to debt, and thus implicitly on the size of $D_{t-1}$, debt policy is linked across time. The value of the firm this period depends in part on the amount of debt $D_{t-1}$ inherited from the past. Similarly, how much debt is chosen this period affects the future value of the firm-the more debt that is acquired now, the smaller is the borrowing ability of the firm in the future, implying either less new investment or more equity finance. The explicit derivation of this relation between $D_{t}$ and future value is complicated. The loss in value from starting the next period with debt $D_{t}$ is simply denoted by $w\left(D_{t}\right)$.

Debt policy now affects the firm's value through these extra terms, $v\left(I_{t}\right)-w\left(D_{t}\right)-n\left(\Delta E_{t}\right)$, as well as through the routes previously described. If equation 3 is used to solve for the value of the firm $(D+E)$, and if, for simplicity, $\delta=\left(\delta_{D} D+\delta_{E} E\right) / V$ and $e=t_{g}$, then, taking into account these extra effects, one obtains

$$
\begin{gathered}
D+E=\frac{(1-e)\left[G_{x}+(1-\tau) X\right]+[\tau+e(1-\tau)-m] r D-\left(1-t_{g}\right) c D}{(1-m) i+\delta} \\
+v\left(I_{t}\right)-w\left(D_{t}\right)-n\left(\Delta E_{t}\right) .
\end{gathered}
$$

Maximizing the right-hand side of 6 with respect to $D_{t}$, and setting $\frac{\partial \Delta E_{t}}{\partial D_{t}}=-1$ implies

$$
\begin{gathered}
{[\tau+e(1-\tau)-m]\left(r+D \frac{\partial r}{\partial D}\right)} \\
+\left(n^{\prime}-w^{\prime}\right)[(1-m) i+\delta]=\left(1-t_{g}\right) \frac{\partial(c D)}{\partial D} .
\end{gathered}
$$

The extra factor, $\left(n^{\prime}-w^{\prime}\right)$, measures the value of expanding investment through extra debt now, compared with leaving the borrowing ability available for future use. The addition of this new term will tend to smooth the time pattern of debt. Due to the'assumed convexity of the costs of changing equity, the firm will want to spread over time any desired readjustment of its debt-value ratio. As a result, it will react less 
to temporary movements in interest rates than to more permanent changes, so short-term interest rates may matter less than the earlier theory suggested.

In addition, this extra term will tend to be positive during periods when the value of new investment is particularly high, or in which cash flow is unusually bad. This effect therefore should produce a cyclical pattern of debt-value ratios, with higher ratios presumably during recessions when cash flow is a problem and lower ratios during recoveries when cash is more plentiful.

\section{Empirical Investigation of Corporate Debt-Value Ratios}

The basic theoretical model discussed, in which a tax advantage to extra debt finance is just offset by bankruptcy-related costs of further debt, implies a strong positive relation between expected nominal interest rates and debt-value ratios. This theory may therefore help to explain both the current high bankruptcy rate during a recession following a period of record-high nominal interest rates and the association between nominal interest rates and debt-value ratios during the 1960s and 1970s.

Testing the various theories empirically is not straightforward, however, since little is known about key elements in the theory. In particular, the bankruptcy cost function, $c$, could easily have shifted over time due to institutional changes. The sophistication of bond covenants has changed over time; the bankruptcy law was amended once in 1979; and case law dealing with bankruptcy has changed continuously. All these factors are difficult to control for empirically. In addition, theory provides little guidance concerning the specific functional form of $c$.

In principle, if $\bar{\tau}$ or $m$ could be measured directly, one could control for the effects described by DeAngelo-Masulis and Miller. ${ }^{32}$ However, data available on the Compustat tape are not sufficient to calculate $\bar{\tau}$, even ex post. Although $m$ has been estimated indirectly in various ways, there is still substantial disagreement over its general size, let alone how its value has changed over time. ${ }^{33}$

32. See DeAngelo and Masulis, "Optimal Capital Structure," and Miller, "Debt and Taxes."

33. See, for example, Huston McCulloch, "The Tax-Adjusted Yield Curve"; Gordon and Malkiel, "Corporation Finance"; and Shiller and Modigliani, "Coupon and Tax Effects." 
A further problem with testing these theories empirically is that if one goes back far enough historically, debt-value ratios are clearly inconsistent with the forecasts from the theories presented in this paper. If there were no corporate taxation, for example, but some agency costs from debt, then debt-value ratios ought to be very low. Yet, according to the figures compiled by Taggart, debt-value ratios were quite high during the first three decades of this century, a period in which corporate tax rates were very low, if not zero. ${ }^{34}$ While there are various theories in the literature that can explain use of debt finance, even without tax effects, these theories do not easily explain the variation over time in debt-value ratios. ${ }^{35}$

The role of the theories presented in this paper in explaining debtvalue ratios should have become much more important in recent years with the sharp growth in tax rates during World War II and the rise in interest rates in the 1970s. I therefore conduct a simple test of the theories with data from the recent past. Since tax rates have been very stable during this period, I focus on the relation between debt-value ratios and interest and inflation rates. ${ }^{36} \mathrm{~A}$ brief summary of what the theories forecast is as follows.

The basic tax advantage-bankruptcy cost model implies that the debtvalue ratio should be positively related to nominal interest rates, and that use of short-term debt ought to depend positively on shorter-term

34. See Robert A. Taggart, Jr., "Secular Patterns in Corporate Finance," Working Paper 810 (National Bureau of Economic Research, 1981).

35. For example, agency costs $c$ need not be minimized when there is no debt-public issues of equity have agency costs as well. For further discussion, see Jensen and Meckling, "Theory of the Firm." For two other nontax explanations for use of debt finance, see Stephen A. Ross, "The Determination of Financial Structure: The Incentive-Signalling Approach,' Bell Journal of Economics, vol. 8 (Spring 1977), pp. 23-40; and Stewart C. Myers and Nicholas S. Majluf, "Stock Issues and Investment Policy When Firms Have Information that Investors Do Not Have," Working Paper 884 (National Bureau of Economic Research, 1982).

36. In this paper I compare the observed levels of the debt-value ratio with the expected values and unexpected changes in interest rates and inflation rates. An alternative approach for examining corporate financial policy would be to compare explicit debt-management activities (new issues and repurchases of debt or equity) with recent unexpected changes in interest rates or inflation. Although this approach would provide more detail on the process of debt management, it does not by itself provide a test of the various theories. Unexpected increases in interest rates, for example, lead to increases in both the desired and the actual debt-value ratio before the firm responds. The action the firm takes (decreasing or increasing debt relative to equity) depends on whether the desired or the actual debt-value ratio changed more in response to events. 
rates primarily. ${ }^{37}$ The effect of inflation, given nominal interest rates, is not clear.

The DeAngelo-Masulis model by itself implies that the debt-value ratio will depend negatively on nominal rates, given inflation, and positively on inflation, given nominal rates.

The Miller model by itself suggests, though not unambiguously, that the debt-value ratio will depend negatively on both nominal interest rates and inflation.

Unexpected increases in the real discount rate will lower firm value, and unexpected increases in nominal rates will lower the market value of longer-term debt. This implies that an unexpected rise in nominal interest rates, given inflation, raises at least book value of debt-to-firm value ratios, while unexpected inflation, given nominal rates, lowers debt-value ratios.

The Modigliani-Cohn hypothesis implies that measured debt-value ratios ought to depend positively on expected inflation. ${ }^{38}$ Unexpected inflation, given nominal rates, ought to have little effect, however, since investors are presumed to discount using nominal rates rather than real rates.

The adjustment costs story suggests higher debt-value ratios in recessions and lower debt-value ratios in recoveries as well as slower responses to changes in incentives.

These theories are not mutually exclusive, so that all the effects described can occur simultaneously. Data necessary to distinguish the role of each theory empirically are not available. Instead, the net relation between debt-value ratios and past interest and inflation rates is measured in an effort to indicate which aspects of the overall theory seem to be most important.

The debt-value ratios were constructed from the data on the 1980 and the 1969 Compustat tapes. These data sets provided annual information

37. Because, according to the arguments above, it may be preferable to refinance the short-term debt rather than change the firm's equity, the desirability of short-term debt will depend as well on expected future interest rates.

38. As discussed in note 20 , the coefficient on inflation in the regression for market debt-value ought to be on the order of $(D / V)(1-e) /\left[(1-m) i+\delta_{E}\right]$. In the estimation, inflation is entered linearly, even though by this argument it ought to interact with other variables. Since all aspects of the relation between debt-value ratios and interest or inflation rates are in principle nonlinear, it did not seem worthwhile to construct just the nonlinearity about whose form the theory is specific. 
on the market value of equity, the book value of debt, and interest paid on preferred stock during 1949-80 for a large sample of publicly traded corporations. The market value of the long-term debt and the preferred stock during 1956-78 were then estimated using data on the industrywide ratios of market to book value of debt and ratios of dividends to prices for preferred stock reported in von Furstenberg, Malkiel, and Watson. ${ }^{39}$ To estimate market values during 1979-80, similar rates were calculated using the data in Moody's Bond Digest. From these data an annual time series was constructed for 1956-80 on the ratios of aggregate market value of debt to aggregate firm value, aggregate book value of debt to aggregate firm value, and aggregate short-term debt to firm value. ${ }^{40}$

Nominal interest rates and inflation not only play a role in the equilibrium models of debt-value ratios, but also can cause changes in debt-value ratios directly, through revaluations. Any measure of the relation between interest rates or inflation and debt-value ratios will capture both sources of effects. Since the firm will react slowly to changing incentives, however, it seems reasonable to suppose that recent changes have caused immediate revaluations but have led to little behavioral response, while less recent changes have been responded to more fully, and any revaluation effects have been largely offset in the interim. The strategy, then, is to capture the behavioral effect of interest rates and inflation through concentrating on the effects of less recent movements in rates, while the effect of more recent movements are presumed to be due mainly to revaluations.

39. See George M. von Furstenberg, Burton G. Malkiel, and Harry S. Watson, "The Distribution of Investment Between Industries: A Microeconomic Application of the ' $q$ ' Ratio," in George M. von Furstenberg, ed., Capital, Efficiency, and Growth (Ballinger, 1980), pp. 395-460.

40. Here the market value of the firm equals the market value of the common equity plus the market value of the preferred stock, plus the market value of the debt (both shortand long-term). To construct these ratios, I used data only on firms whose reported debt and equity figures are year-end values (between November and January). To construct the time series I used the adjusted procedure described in Gordon and Malkiel, "Corporation Finance," which attempts to lessen any bias, caused by having a less representative sample of firms in earlier years, through focusing on rates of change in debt and total value between each two consecutive years for firms reporting data in both years. During 196168 , the period for which data were available, I averaged the calculated ratios. For shortterm debt, data on debt in current liabilities were used, which include not only short-term debt but also long-term debt coming due within the year. 
To justify this strategy, assume that the firm's slow adjustment to changes can be approximated by a partial adjustment model, whereby

$$
\left(\frac{D}{V}\right)_{t}=\left(\frac{D}{V}\right)_{t-1}+(1-\lambda)\left[\left(\frac{D}{V}\right)_{t-1}^{*}-\left(\frac{D}{V}\right)_{t-1}\right]+S_{t} .
$$

Here, $(D / V)_{t}$ is the actual debt-value ratio in the $t$ th period; $(D / V)_{t}^{*}$ is the optimal debt-value ratio, ignoring adjustment costs; and $S_{t}$ is the unexpected change in $(D / V)_{t}$. To state the argument simply, assume that the desired debt-value ratio depends on a single nominal interest rate, $r$, and the shock term, $S_{t}$, depends on the unexpected change in this rate, $\epsilon^{r}$. Stated explicitly, assume that

$$
\begin{aligned}
(D / V)_{t}^{*} & =\alpha r_{t} \\
S_{t} & =\beta \epsilon^{r} .
\end{aligned}
$$

Again for simplicity, assume that the interest rate, $r_{t}$, approximately follows a random walk, so that $r_{t}=\sum_{j=0}^{\infty} \epsilon_{t-j}^{r}$. Given these assumptions, $(D / V)_{t}$ can be expressed as

$$
(D / V)_{t}=\sum_{k=0}^{\infty} \epsilon_{t-k}^{r}\left[\lambda^{k} \beta+\left(1-\lambda^{k}\right) \alpha\right] .
$$

The coefficient on $\epsilon_{t-k}^{r}$ is a weighted average of the equilibrium effect $\alpha$ and the revaluation effect $\beta$, with the weight on $\alpha$ approaching one for earlier values of $\epsilon_{t-k}^{r}$ and the weight on $\beta$ approaching 1 for more recent values of $\epsilon_{t-k}^{r}$.

Another problem that must be faced is that the two interest rate series on corporate bonds are to a degree endogenous-higher debt-value ratios imply higher risk, and thus higher coupons on any debt issues. The procedure chosen for handling these two problems together is as follows. I constructed the average values of the long-term new issue AA utility bond interest rate, the six-month finance paper rate, and the inflation rate, for the calendar year preceding the debt-value ratio observation. ${ }^{41}$

41. The interest rate data are from the Salomon Brothers Center, An Analytical Record of Yields and Yield Spreads. The inflation rate is measured using the CPI through 1958, and the fixed weight price index for personal consumption expenditures other than food and energy was taken from the U.S. Bureau of Economic Analysis, national income and product accounts, since 1959 . 
Each of the two interest rate variables were then divided into three orthogonal components: ${ }^{42}$ the forecasted value using a set of exogenous instruments from the previous December, the improvement in the forecast using exogenous instruments from the current year, and the remaining residual, which may be endogenous. The first component was then used to capture the equilibrium effect, and the second to capture any revaluation effect. In contrast, I assumed that the inflation rate was exogenous, and so broke it down into just two components, the forecast using exogenous data from the previous December ${ }^{43}$ and the residual. Both were then included in the debt-value regressions. ${ }^{44}$

The final problem is how best to control for cyclical effects. While it would be possible to construct an approximate measure of cash-flow pressure for these firms, such a measure would certainly be endogenous-cash flow, new investment, and the current debt-value ratios are all closely linked according to the theories. Rather than constructing this measure and using instruments, I included instead a standard cyclical variable, the layoff rate. Its average value during the current year was included in the regressions.

I then estimated three regressions using annual data from 1956 to

42. For long-term corporate rates, the first component was constructed by using as instruments the six-month Treasury bill rate and the long-term government bond rate both from the previous December; the second component was constructed using the average long-term government bond rate from the current year. Similarly, for short-term corporate rates, the first component was constructed using the six-month Treasury bill rate and the two-year government note rate from the previous December, and the second component, using the average six-month Treasury bill rate during the current year. Government rates are free from any endogeneity due to default risk. Since corporate and government securities markets are closely linked, it is possible that a shift in the composition of corporate securities may affect the price of government securities, but this link was believed to be sufficiently weak to be ignored.

43. The average inflation rate during the current year was forecast using the average inflation rate in the previous year, the six-month Treasury bill rate, and the two-year government note rate from the previous December.

44. Only inflation forecasts over a short time-horizon are captured here. The shortterm inflation rate plays a key role in measuring effects of inflation on tax rates. Also, the size of the bias under the Modigliani and Cohn hypothesis was derived in terms of the short-term rate. Revaluation effects, however, depend on longer-term inflationary forecasts. Such forecasts are difficult to construct, and were not attempted here. To the degree that unexpected changes in nominal interest rates are more closely associated with unexpected changes in long-term inflation forecasts than are unexpected changes in shortterm inflation rates, the coefficient on the unexpected nominal interest rate may capture in part the effects of inflation. 
Table 1. Debt-Value Regressions, 1956-80 ${ }^{\text {a }}$

\begin{tabular}{|c|c|c|c|}
\hline \multirow[b]{2}{*}{$\begin{array}{l}\text { Independent variable and } \\
\text { summary statistic }\end{array}$} & \multicolumn{3}{|c|}{ Dependent variable } \\
\hline & $\begin{array}{c}\text { Ratio of } \\
\text { market debt to } \\
\text { market value }\end{array}$ & $\begin{array}{l}\text { Ratio of } \\
\text { book debt to } \\
\text { market value }\end{array}$ & $\begin{array}{l}\text { Ratio of } \\
\text { short-term debt } \\
\text { to market value }\end{array}$ \\
\hline Intercept & $\begin{array}{c}-0.051 \\
(0.046)\end{array}$ & $\begin{array}{c}-0.146 \\
(0.058)\end{array}$ & $\begin{array}{r}-0.049 \\
(0.015)\end{array}$ \\
\hline \multicolumn{4}{|l|}{ Interest rate } \\
\hline Expected long-term rate & $\begin{array}{c}0.065 \\
(0.013)\end{array}$ & $\begin{array}{c}0.084 \\
(0.016)\end{array}$ & $\begin{array}{c}0.015 \\
(0.004)\end{array}$ \\
\hline Unexpected long-term rate & $\begin{array}{c}0.057 \\
(0.031)\end{array}$ & $\begin{array}{c}0.050 \\
(0.039)\end{array}$ & $\begin{array}{c}0.003 \\
(0.010)\end{array}$ \\
\hline Expected short-term rate & $\begin{array}{c}-0.026 \\
(0.008)\end{array}$ & $\begin{array}{c}-0.024 \\
(0.010)\end{array}$ & $\begin{array}{c}0.001 \\
(0.003)\end{array}$ \\
\hline Unexpected short-term rate & $\begin{array}{r}-0.014 \\
(0.010)\end{array}$ & $\begin{array}{c}-0.012 \\
(0.013)\end{array}$ & $\begin{array}{c}0.001 \\
(0.003)\end{array}$ \\
\hline Expected inflation & $\begin{array}{l}-0.016 \\
(0.009)\end{array}$ & $\begin{array}{c}-0.025 \\
(0.011)\end{array}$ & $\begin{array}{c}-0.008 \\
(0.003)\end{array}$ \\
\hline Unexpected inflation & $\begin{array}{c}0.013 \\
(0.005)\end{array}$ & $\begin{array}{c}0.015 \\
(0.006)\end{array}$ & $\begin{array}{c}0.003 \\
(0.002)\end{array}$ \\
\hline Layoff rate & $\begin{array}{c}0.027 \\
(0.014)\end{array}$ & $\begin{array}{c}0.042 \\
(0.017)\end{array}$ & $\begin{array}{c}0.004 \\
(0.005)\end{array}$ \\
\hline \multicolumn{4}{|l|}{ Summary statistic } \\
\hline$R^{2}$ & 0.896 & 0.916 & 0.894 \\
\hline Standard error & 0.025 & 0.031 & 0.008 \\
\hline
\end{tabular}

Source: Regressions as described in the text, using the Compustat data tape.

a. The figures in parentheses are the standard errors.

1980 , with the dependent variables being the ratios of market value of debt to market value of the firms, book value of debt to market value of the firms, and short-term debt to market value of the firms. In each equation, the independent variables used were the expected long-term interest rate, the unexpected change in the long-term rate, the expected short-term interest rate, the unexpected change in the short-term rate, the expected inflation rate, the unexpected change in the inflation rate, and the layoff rate. The results are reported in table 1 .

Regression results from twenty-five observations and eight estimated coefficients must be viewed with some caution. Standard errors in particular could be biased due to autocorrelation or heteroscedasticity. However, certain results do stand out. In all three regressions the expected long-term interest rate plays a dominant role. Its coefficients are significant statistically, and the implied economic effect is extremely 
large. For example, each point rise in the nominal interest rate raises the market value of the debt-value ratio by 0.065 . This is a very large movement, given the historic range in the ratio. This coefficient is consistent with the implications of the tax advantage-bankruptcy cost model and inconsistent with the DeAngelo-Masulis or Miller models. The latter effects, while undoubtedly present, do not appear to be playing an important role here.

The coefficients on the unexpected long-term interest rate are also large and positive, a result consistent with the revaluation story. Their size is close to that of the coefficients of the expected long-term rate, which suggests either that the revaluation effect and the behavioral effect are similar in size or that the adjustment process suggested here fails to capture the difference between the two effects.

The coefficients on the two short-term interest rate variables are harder to explain. While adjustment costs imply that the expected shortterm rate should play a lesser role, its predicted effect from the tax advantage-bankruptcy cost model is still positive, particularly in explaining the use of short-term debt. ${ }^{45}$ In contrast, its coefficient in the shortterm debt equation is basically zero, while in the other two equations it is significantly negative, though much smaller in absolute value than the coefficient on expected long-term rates. The negative coefficient on the unexpected component is inconsistent with the revaluation effect, though again the coefficient is small relative to that on the unexpected component of long-term rates. Perhaps this variable is capturing cyclical effects.

The coefficient on expected inflation is also negative and significant, though not very large. Its value is significantly different, however, from the large positive value forecast by the Modigliani-Cohn hypothesis. One possible explanation of the negative value is an associated rise in personal marginal tax rates, weakening the tax advantage to debt.

The positive coefficient on unexpected inflation is inconsistent with the revaluation effect. Unexpected inflation may also in part be a cyclical proxy-unexpected inflation may signal a future tightening in monetary policy and an associated drop in the value of the firm.

Finally, the explicit cyclical variable, the layoff rate, is significant and indicates higher debt-value ratios during recessions, as expected. Since unexpected short-term rates and unexpected inflation may also be

45. While the DeAngelo and Masulis and the Miller models imply negative effects, they do not help rationalize a negative effect of just short-term rates. 
playing a cyclical role, the size and exact timing of the cyclical effect are hard to evaluate.

\section{Conclusion}

In this paper I have examined both theoretically and empirically the links between interest rates, inflation, and debt-value ratios. In the basic theory explored there is a presumed tax advantage to debt finance due to the deductibility of nominal interest payments at the corporate level. In equilibrium this tax savings is offset by bankruptcy and agency costs arising from extra debt. Since the value of the tax savings per dollar of debt is larger when nominal interest rates increase, the firm's optimal debt-value ratio should also increase. In the empirical work it was found that debt-value ratios and nominal interest rates have in fact been closely linked.

The findings indicate that as nominal interest rates rise, bankruptcy and agency costs of debt will rise also. In fact, following the tremendous rise in nominal rates in 1980, the United States is now experiencing the highest business failure rate since the 1930s. This association between bankruptcy costs and nominal interest rates that are raised by inflation provides another justification for the argument that inflation is costly. 


\section{Comments and Discussion}

John B. Shoven: The determination of corporate financial policy has always been hard to model satisfactorily. Franco Modigliani and Merton $\mathrm{H}$. Miller originally argued that the debt-equity ratio did not matter in the sense that it did not affect the total value of the firm. However, when taxes are included in the argument, it is evident that the government's claim is eroded when the debt-equity ratio is increased. So without bankruptcy costs, as in the Modigliani-Miller model, this leads to 100 percent debt finance. By the same reasoning, the bankruptcy probability and bankruptcy costs limit the extent to which a firm wants to use debt finance. These considerations lead to what Gordon refers to as the model of tax advantage versus bankruptcy costs in which, at the margin, the tax advantage of debt is just offset by the expected bankruptcy costs that additional debt incurs.

Other models argue that there is no tax advantage to debt at the margin because at the optimal debt-equity ratio the combination of corporate and personal tax rates are the same for both sources of finance. This condition can be maintained as the aggregate debt-equity ratio changes. Either the effective corporate tax rate can change-which is suggested by the model developed by Harry DeAngelo and Ronald W. Masulis or the personal tax rate can change as Miller suggested in his presidential address in the Journal of Finance.

Gordon shows that, in the tax advantage-bankruptcy costs model, as nominal interest rates rise the tax advantage to debt climbs, leading firms to choose a higher debt-value ratio.

I do not think this result, in theory, is quite as unambiguous as the paper suggests. At a fixed debt-equity ratio, high interest rates not only give a higher tax shelter per dollar of debt, but they also raise the costs 
and probability of bankruptcy for firms with debt obligations. The net result is probably as Gordon claims. But I would have liked to see this second effect modeled explicitly.

Both the DeAngelo-Masulis model and the Miller model would predict that at higher interest rates firms would want a lower debt-equity ratio. This difference could be used to choose empirically between the competing models.

One problem I have with the model in this paper is that the purchasers of debt and equity have the same attitude toward risk and the same tax rate. This assumption seems less realistic than a sorting model in which those who buy debt are more risk averse and have different personal tax rates than those who buy equities.

In the empirical work the equations that are estimated do not really test the model and, in some ways, do not represent it well. First, no tax rates appear in the regressions, although taxes are central to the tax advantage-bankruptcy cost model. Second, there is a lot of multicolinearity among the independent variables. There are two interest rates and expected inflation on the right-hand side, making it difficult to prove which of the several variables are determining the debt-value ratio.

Another problem is that interest rates may determine debt-value ratios, but debt-value ratios may also affect interest rates. So it is unclear whether one estimated the demand curve, the supply curve, or neither. Gordon attempts to get around that by using government rather than corporate interest rates. But I am not sure that technique handles the problem satisfactorily.

Perhaps the biggest problem is that the debt-value ratio to a large degree is determined by what is happening to the value of equity in the denominator. Interest rates and the stock market are probably cyclically related, with high interest rates leading to a weak stock market. Therefore rising interest rates would cause the debt-value ratio to increase through this effect on equity prices.

The model in the paper predicts that when interest rates are high, firms sell bonds and buy back stock so as to adjust their debt-equity ratio through an active restructuring of the firm's capital. But because the value of equity is changing with stock prices, we may not be observing this tax-arbitrage bankruptcy-cost optimization at all.

For these reasons, I was not convinced by the empirical work that I should choose Gordon's model over alternatives with different implica- 
tions. There are just too many problems in interpreting the regressions that are shown.

\section{General Discussion}

Stanley Fischer suggested that Gordon estimate his model using the marginal-debt equity ratios for new issues rather than the ratio of the total stock of debt and equity. In this way, the analysis would look directly at the way firms raise funds in a given year rather than trying to infer that from data that show mainly how funds have been raised over the firms' past history. James Tobin observed that the average debtequity ratio is not easily adjustable within a one-year period and that firms do not make big switches between outstanding debt and outstanding equity by repurchasing one or the other. For that reason, he suggested that Gordon's empirical estimates should explicitly allow for lagged adjustment.

John Campbell suggested that some of Gordon's reported coefficients could be interpreted differently from the way they were in the paper. He questioned whether the coefficient on the long-term interest rate represents the impact of the perceived real long-term rate. He reasoned that the long-term interest rate contains some component reflecting expectations of future inflation, and these expectations may be more accurately reflected in this variable than in the current inflation rate. Campbell was also skeptical of Gordon's decomposition of interest and inflation rates into expected and unexpected components. Since the expected component is estimated on the basis of a regression that contains information for the entire period, there is an implicit and probably erroneous assumption that agents knew what those coefficients were at the beginning of the period. Much of the "expected" component might consequently have been unexpected.

Charles Holt commented on the estimate, cited by Gordon, that the legal and administrative costs of bankruptcy are only about 5 percent of a firm's outstanding liabilities. He observed that these represent only a fraction of the total costs of bankruptcy. When the Internal Revenue Service auctions off the assets of bankrupt corporations, the assets usually command a price that is only 10 to 25 percent of their usual market value. 